

\section{NOTICE}

The submitted manuscript has been offered by an employee of the Alliance for Sustainable Energy, LLC (ASE), a contractor of the US Government under Contract No. DE-AC36-08-GO28308. Accordingly, the US Government and ASE retain a nonexclusive royalty-free license to publish or reproduce the published form of this contribution, or allow others to do so, for US Government purposes.

This report was prepared as an account of work sponsored by an agency of the United States government. Neither the United States government nor any agency thereof, nor any of their employees, makes any warranty, express or implied, or assumes any legal liability or responsibility for the accuracy, completeness, or usefulness of any information, apparatus, product, or process disclosed, or represents that its use would not infringe privately owned rights. Reference herein to any specific commercial product, process, or service by trade name, trademark, manufacturer, or otherwise does not necessarily constitute or imply its endorsement, recommendation, or favoring by the United States government or any agency thereof. The views and opinions of authors expressed herein do not necessarily state or reflect those of the United States government or any agency thereof.

Available electronically at http://www.osti.gov/bridge

Available for a processing fee to U.S. Department of Energy and its contractors, in paper, from:

U.S. Department of Energy

Office of Scientific and Technical Information

P.O. Box 62

Oak Ridge, TN 37831-0062

phone: 865.576 .8401

fax: 865.576 .5728

email: mailto:reports@adonis.osti.gov

Available for sale to the public, in paper, from:

U.S. Department of Commerce

National Technical Information Service

5285 Port Royal Road

Springfield, VA 22161

phone: 800.553.6847

fax: 703.605.6900

email: orders@ntis.fedworld.gov

online ordering: http://www.ntis.gov/ordering.htm 


\title{
Rapid Modeling of Power Electronics Thermal Management Technologies
}

\author{
Kevin Bennion and Kenneth Kelly \\ National Renewable Energy Laboratory \\ Center for Transportation Technologies and Systems \\ Golden, Colorado, USA
}

\begin{abstract}
A methodology was developed to rapidly evaluate trade-offs associated with alternative packaging configurations and thermal management technologies for power electronics packaging. The methodology includes the integration of available experimental correlations, computational fluid dynamics results, parametric 3D finite element analysis (FEA) thermal models, and established heat exchanger analysis techniques. The parametric 3D FEA model enables sensitivity studies related to the power module package configuration and cooling technologies. This paper focuses on the study of alternative cooling technologies as they are applied to a fixed power module package. The methodology is applied to a double-sided power module package for several alternative cooling technologies.
\end{abstract}

Keywords - power electronics, thermal management, thermal control, thermal resistance, hybrid electric vehicle, electric vehicle, fuel cell vehicle

\section{INTRODUCTION}

Electric drive systems, which include electric machines and power electronics, are a key enabling technology for advanced vehicle propulsion systems that reduce the dependence of the U.S. transportation sector on petroleum. However, to penetrate the market, these electric drive technologies must enable vehicle solutions that are economically justifiable. As critical components of the electric drive system are made smaller, lighter, and more cost effective, heat removal becomes an increasing challenge.

To support the development of environmentally friendly transportation technologies that reduce petroleum consumption, the U.S. Department of Energy (DOE) supports research and development in electric drive systems through the Vehicle Technologies program. The Advanced Power Electronics and Electric Machines (APEEM) R\&D team develops power electronics technologies applicable to hybrid electric vehicles (HEVs), plug-in hybrid electric vehicles (PHEVs), fuel cell vehicles, and electric vehicles. The APEEM team includes members at DOE and researchers at the national laboratories who work through the FreedomCAR and Fuels Partnership with the U.S. automotive industry. As part of this partnership, DOE's National Renewable Energy Laboratory (NREL) leads R\&D activities in the thermal control of advanced power electronics and electric machines.

The authors would like to acknowledge the support provided by Susan Rogers, Technology Development Manager, Advanced Power Electronics and Electric Machines, DOE Vehicle Technologies Program.
To successfully integrate advanced power electronics concepts into vehicle applications, the thermal limitations of the semiconductor devices must be addressed. Critical semiconductor components such as insulated gate bipolar transistors (IGBTs) and diodes are sensitive to temperature and must operate below fixed temperature limits of $125^{\circ} \mathrm{C}$ to $150^{\circ} \mathrm{C}$ for silicon devices [1]. The vehicle must achieve its performance requirements as it operates within this thermal limitation while meeting the goals for system reliability, cost, volume, and weight. The APEEM program emphasizes the importance of cost, weight, volume, efficiency, and reliability for the widespread use of electric drive systems in vehicle applications [1], and each of these areas has a direct relation to the thermal control of electric drive systems.

The design of the thermal control system is directly tied to the packaging configuration of the semiconductor devices and the overall vehicle thermal management system. The direct link between semiconductor packaging and thermal control is critical $[2,3]$ in that conventional methods to increase power output by increasing silicon area are too expensive in terms of cost and volume. For this reason alternative methods are needed to improve heat removal of innovative high power APEEM systems. Also, thermal control is tied to the overall vehicle thermal management strategy. For example, one research goal under the FreedomCAR and Fuels Partnership is to use only one cooling loop for an HEV [1,4]. A single cooling loop cools the power electronics, electric machines, and internal combustion engine. The power electronics inverter would thus have to tolerate inlet coolant temperatures $\left(T_{c, i}\right)$ up to $105^{\circ} \mathrm{C}[1]$.

Addressing goals associated with performance, cost, weight, and volume requires investigation into multiple thermal control technology pathways that involve the vehicle propulsion configuration (such as HEV or PHEV), component use (vehicle drive cycles), cooling system configuration, power electronics package configuration, and heat exchanger design. A systems approach is necessary to investigate the multiple options and trade-offs associated with the items mentioned above. Analysis techniques are needed that allow researchers to quickly investigate the system-level impacts of potential technologies and evaluate trade-offs to understand the design space. This paper outlines one such method for investigating the system-level performance of power semiconductor package configurations and heat exchanger technologies. 


\section{APPROACH}

The APEEM program area within the DOE Vehicle Technologies Program is currently developing a suite of advanced thermal control technologies, including single-phase and two-phase jet impingement, air cooling, low thermal resistance semiconductor packaging structures, and improved thermal interface materials [5]. Because of the number of available packaging and thermal control options, a method for analyzing the system thermal performance was developed. The developed methodology, general in nature, allows the system performance characterization of multiple package and heat exchanger technology options within a consistent framework. The multistep approach for this work is summarized in Fig. 1. The process involves a merging of techniques to characterize heat transfer technologies and fluid flow with techniques that characterize the thermal performance of packages for power electronics applications. The end result is the ability to evaluate the total system thermal performance. This allows the evaluation of multiple heat exchanger technologies applied to power semiconductor package configurations. The intent of this paper is to provide an example of the analysis techniques on a power semiconductor package of interest.

\section{A. Package Selection and Thermal Characterization}

First (as shown at the bottom of Fig. 1), a double-sided package for a power semiconductor module was selected that consisted of one IGBT and one diode [2,3]. This package is shown in Fig. 2; this package was selected because it is used in a commercial HEV and allows cooling on both sides of the package. A double-sided package was of interest because previous analysis showed the potential benefit of doublesided cooling for power semiconductor packages [6]. The

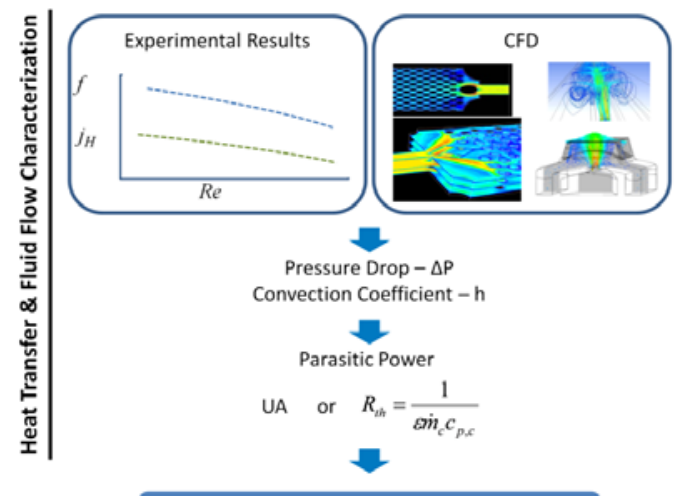

System Performance

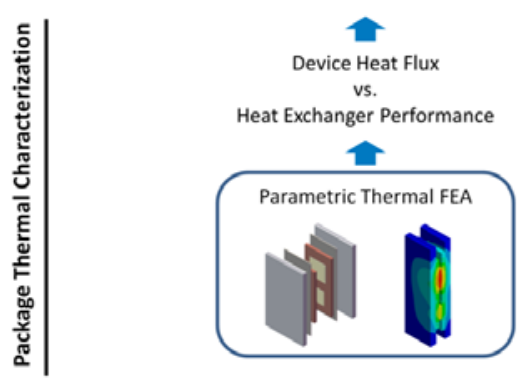

Figure 1. Thermal system analysis process. package was also of interest because it was part of an APEEM benchmarking effort conducted by Oak Ridge National Laboratory (ORNL) [7]. Fig. 3 shows an exploded view of the layers used as part of the thermal analysis described in this report. Table I provides the material information associated with the layer labels in Fig. 3 based on information provided by ORNL through its benchmarking work and on $[2,3]$.

The CAD software "SolidWorks" was used to construct a three-dimensional solid model of the package. The geometry was then imported into the software "ANSYS Workbench" for thermal analysis using the finite element analysis (FEA) methodology (see Fig. 4). For this analysis, a constant IGBT to diode loss ratio of 3:1 was used (see Figs. 4, 5, and 6). The IGBT and diode heat loads were applied with volumetric heat generation for each device. A convective heat transfer coefficient was applied to the top and bottom surfaces in Fig. 4

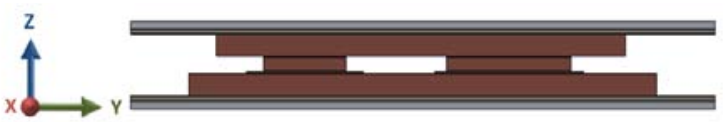

Figure 2. Double-sided package showing side view of IGBT and diode with a $50 \mathrm{~mm}$ by $30 \mathrm{~mm}$ heat exchanger base area.

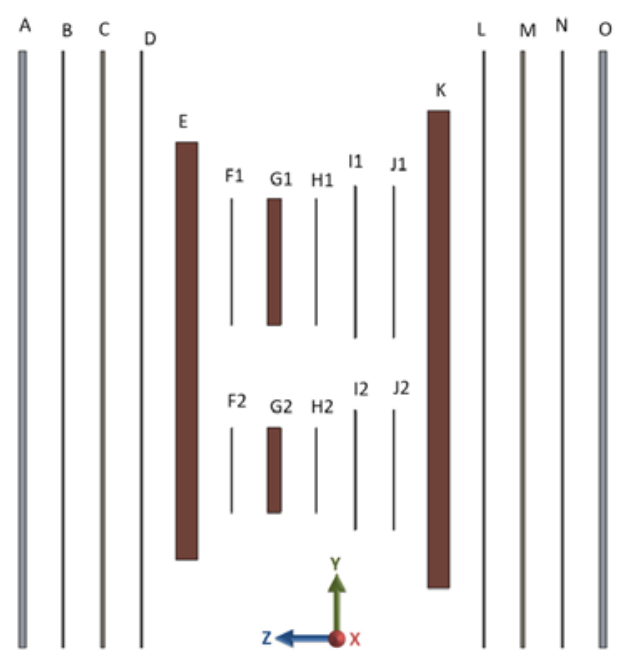

Figure 3. Double-sided package showing side view of IGBT and diode.

TABLE I

MATERIAL KEY

\begin{tabular}{|l|l|c|c|c|}
\hline Index & \multicolumn{1}{|c|}{ Material } & $\mathbf{X}[\mathbf{m m}]$ & $\mathbf{Y}[\mathbf{m m}]$ & $\mathbf{Z}[\mathbf{m m}]$ \\
\hline $\mathrm{A}$ & Heat sink: Al & 30 & 50 & 0.6 \\
\hline $\mathrm{B}$ & TIM: Grease & 21 & 50 & 0.1 \\
\hline $\mathrm{C}$ & Substrate: SiN & 21 & 50 & 0.3 \\
\hline $\mathrm{D}$ & TIM: Grease & 21 & 50 & 0.1 \\
\hline $\mathrm{E}$ & Heat Spreader: Cu & 21 & 35 & 1.85 \\
\hline F1, F2 & Solder & $10.6,7.1$ & $10.6,7.1$ & 0.076 \\
\hline $\mathrm{G} 1, \mathrm{G} 2$ & Spacer: $\mathrm{Cu}$ & $10.6,7.1$ & $10.6,7.1$ & 1.14 \\
\hline $\mathrm{H} 1, \mathrm{H} 2$ & Solder & $10.6,7.1$ & $10.6,7.1$ & 0.076 \\
\hline $\mathrm{I} 1, \mathrm{I} 2$ & IGBT, Diode: $\mathrm{Si}$ & $12.7,10$ & $12.7,10$ & 0.145 \\
\hline $\mathrm{J} 1, \mathrm{~J} 2$ & Solder & $12.7,10$ & $12.7,10$ & 0.076 \\
\hline $\mathrm{K}$ & Heat Spreader: Cu & 21 & 40 & 1.85 \\
\hline $\mathrm{L}$ & TIM: Grease & 21 & 50 & 0.1 \\
\hline $\mathrm{M}$ & Substrate: SiN & 21 & 50 & 0.3 \\
\hline $\mathrm{N}$ & TIM: Grease & 21 & 50 & 0.1 \\
\hline $\mathrm{O}$ & Heat sink: Al & 30 & 50 & 0.6 \\
\hline
\end{tabular}


to generate the desired net UA (heat transfer coefficient times area) at a specified fluid temperature. To determine the maximum allowable IGBT heat flux for a given UA value, an iterative approach was used within "DesignXplorer" of "ANSYS Workbench." The volumetric heat load of the IGBT was determined based on the targeted maximum temperature limit of the IGBT device. This temperature limit is referred to as the maximum junction temperature $\left(T_{j}\right)$ throughout this paper. Once this maximum allowable heat load was determined, the process was performed again for another UA boundary condition. Two junction temperature limits of $150^{\circ} \mathrm{C}$ and $175^{\circ} \mathrm{C}$ were used for the analysis. In addition, two coolant temperatures were used $\left(70^{\circ} \mathrm{C}\right.$ and $\left.105^{\circ} \mathrm{C}\right)$. The $70^{\circ} \mathrm{C}$ coolant temperature is based on current coolant loops used in $\mathrm{HEV}$ applications, and $105^{\circ} \mathrm{C}$ is based on the upper temperature limit target from DOE's APEEM R\&D team [1]. Fig. 4 shows a temperature profile of the package for a sample heat load condition, while Fig. 5 shows the heat flow paths through the asymmetric package construction. Fig. 6 shows the temperature path through the package for the IGBT, where the large temperature differences occur across the thin thermal interface material (TIM) layers.

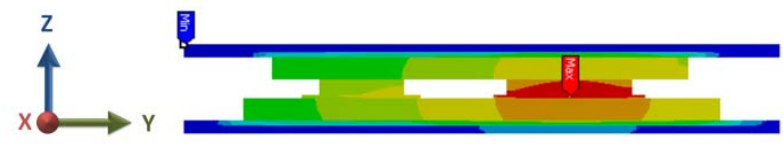

Figure 4. Sample of temperature distribution on ANSYS FEA model (coolant temperature $70^{\circ} \mathrm{C}$, IGBT junction temperature $150^{\circ} \mathrm{C}$, net effective UA applied to each side $10 \mathrm{~W} / \mathrm{K}$, IGBT heat flux $170.7 \mathrm{~W} / \mathrm{cm}^{2}$, IGBT to diode loss ratio $3: 1)$.

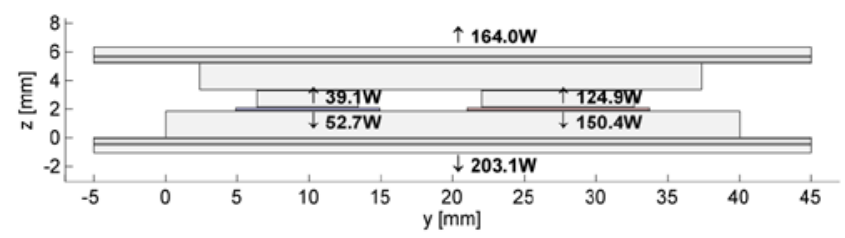

Figure 5. Heat flow paths from ANSYS FEA model (coolant temperature $70^{\circ} \mathrm{C}$, IGBT junction temperature $150^{\circ} \mathrm{C}$, net effective UA applied to each side $10 \mathrm{~W} / \mathrm{K}$, IGBT heat flux $170.7 \mathrm{~W} / \mathrm{cm}^{2}$, IGBT to diode loss ratio $3: 1$ ).

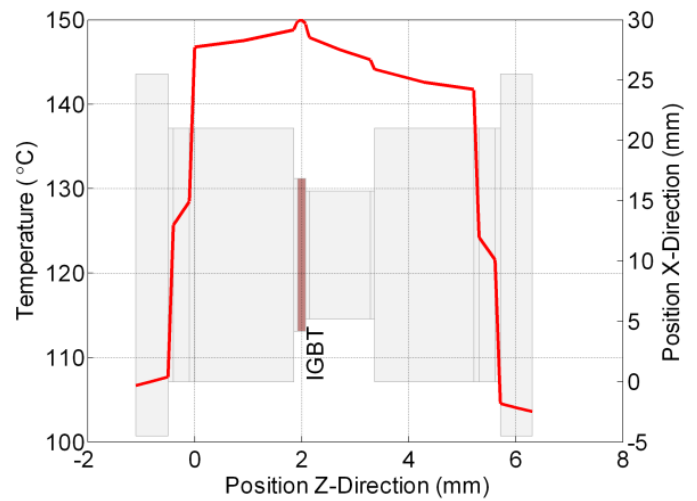

Figure 6. Staight line IGBT temperature profile through package to the heat sink base from ANSYS FEA model. Note the $\mathrm{z}$ axes scale is magnified to show detail (coolant temperature $70^{\circ} \mathrm{C}$, IGBT junction temperature $150^{\circ} \mathrm{C}$, net effective UA applied to each side $10 \mathrm{~W} / \mathrm{K}$, IGBT heat flux $170.7 \mathrm{~W} / \mathrm{cm}^{2}$, IGBT to diode loss ratio $3: 1$ ).
The parametric ability of the FEA thermal model allows for sensitivity studies associated with multiple aspects of the package design and not just the heat exchanger performance. For this demonstration, the package performance curves were generated using different material properties for the TIM. A baseline TIM material was selected from information generated as part of NREL's characterization of TIM thermal performance [8]. To see the impact of improvements to the thermal interfaces, a $5 \mathrm{X}$ and $10 \mathrm{X}$ improvement in the interface thermal resistances were considered (Table II).

\section{B. Heat Exchanger Characterization - Finned}

As shown at the top of Fig. 1, another step in the process required characterizing the thermal performance of various thermal control technologies. This can be performed through computational fluid dynamics (CFD) analyses, analytical solutions, and experimental correlations. Each of these methods will be discussed in this paper.

The first selected thermal control technique approximates the actual finned heat exchanger used in a vehicle application. The approximated geometry is shown in Fig. 7, and the key parameters are listed in Table III. The fluid flow assumptions are highlighted in Table IV. The coolant fluid was assumed to be a 50/50 (by mass) mix of water ethylene glycol with properties based on [9]. The actual power electronics system includes 12 stages of power modules placed between 13 cooling channels running between the inlet and outlet manifolds. For this analysis, we assumed that each stage received the same coolant flow on each side of the package so the total flow rate was divided by 12 instead of 13 .

TABLE II

TIM PROPERTIES

\begin{tabular}{|c|c|c|c|}
\hline & $\begin{array}{c}\text { Thermal } \\
\text { Conductivity } \\
(\mathbf{W} / \mathbf{m}-\mathbf{K})\end{array}$ & $\begin{array}{c}\text { Thickness } \\
\mathbf{( m m )}\end{array}$ & $\begin{array}{c}\text { Thermal } \\
\text { Resistance } \\
\left(\mathbf{m m}^{\mathbf{2}} \mathbf{- K} / \mathbf{W}\right)\end{array}$ \\
\hline Base Case & 1.5 & 0.10 & 66.7 \\
\hline $5 \mathrm{X}$ & 7.5 & 0.10 & 13.3 \\
\hline $10 \mathrm{X}$ & 15 & 0.10 & 6.7 \\
\hline
\end{tabular}

TABLE III

FIN PARAMETERS

\begin{tabular}{|l|l|c|}
\hline Parameter & \multicolumn{1}{|c|}{ Definition } & Value \\
\hline $\mathrm{a}$ & Fluid channel width & $0.9 \mathrm{~mm}$ \\
\hline $\mathrm{b}$ & Fin or channel height & $2.0 \mathrm{~mm}$ \\
\hline $\mathrm{t}$ & Fin thickness & $0.6 \mathrm{~mm}$ \\
\hline 1 & Channel length & $50.0 \mathrm{~mm}$ \\
\hline
\end{tabular}

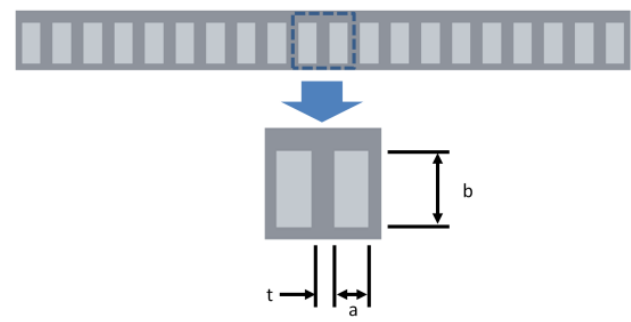

Figure 7. Heat exchanger geometry for one side of the module package. 
TABLE IV

FLUID FLOW ASSUMPTIONS

\begin{tabular}{|l|l|}
\hline \multicolumn{1}{|c|}{ Definition } & \multicolumn{1}{c|}{ Value } \\
\hline Total system volumetric flow $[2,3]$ & $12 \mathrm{~L} / \mathrm{min}$ \\
\hline Coolant inlet temperature & $70^{\circ} \mathrm{C}$ \\
\hline Cooling stages & 12 \\
\hline Number of cooling channels per side & 20 \\
\hline Channel mass flow rate & $0.00043 \mathrm{~kg} / \mathrm{s}$ \\
\hline
\end{tabular}

The finned heat exchanger performance was estimated using two different methods. The first involved running a CFD simulation of a single channel; the second involved an analytical solution for fully developed laminar flow through a rectangular cross section [10]. For the CFD simulation, a model of a single channel was developed using the ANSYS software programs "Workbench" and "CFX." An entry region was applied to the model to ensure fully developed fluid flow, although the model did not enforce a fully developed thermal entry region. Convergence was confirmed along with mesh independence. The average heat transfer coefficient over the total cooled surface was determined according to equation 1, where $\mathrm{q}$ is the heat transferred to the fluid, $\mathrm{A}_{\mathrm{s}}$ is the total surface area cooled by the fluid, $\mathrm{T}_{\mathrm{S}}$ is the average surface temperature at the interface, and $\mathrm{T}_{\text {ref }}$ is the inlet temperature of the fluid. While the heat transfer coefficient was of interest, the parameter needed for the analysis was the overall UA of the heat exchanger. This can be determined from the fin surface temperature and area $\left(\mathrm{UA}_{\mathrm{s}}\right)$ as shown in equation 2, or from the base temperature and area before the fins $\left(\mathrm{UA}_{\mathrm{b}}\right)$ as shown in equation $3 ; \mathrm{T}_{\mathrm{b}}$ is the average base surface temperature. The base area corresponds to the area in the ANSYS model (Fig. 4) to which the UA value was applied. The $\mathrm{UA}_{b}$ results were used for this analysis. The results were multiplied by $n$ (number of channels) to get an estimate for the total heat exchanger performance.

$$
\begin{aligned}
h & =\frac{q}{A_{S}\left(T_{s}-T_{r e f}\right)} . \\
U A_{s} & =n\left[\frac{q}{\left(T_{s}-T_{r e f}\right)}\right] . \\
U A_{b} & =n\left[\frac{q}{\left(T_{b}-T_{r e f}\right)}\right] .
\end{aligned}
$$

The second approach used to evaluate the performance of the finned heat exchanger was to use available analytical solutions for fully developed laminar flow through rectangular channels [10]. Using these techniques, approximate values for the Nusselt number $\left(\mathrm{Nu}_{\mathrm{D}}\right)$ and the Darcy/Moody friction factor (f) multiplied by Reynolds number $\left(\mathrm{Re}_{\mathrm{D}}\right)$ were estimated. For this analysis, a uniform surface temperature was assumed. Based on the geometry in Table III, $\mathrm{Nu}_{\mathrm{D}}$ was fixed at a value of 3.68 and $\mathrm{fRe}_{\mathrm{D}}$ was fixed at 65 . The average heat transfer coefficient through the channel was calculated according to equation 4 , where $\mathrm{k}$ is the fluid thermal conductivity and $\mathrm{D}_{\mathrm{h}}$ is the hydraulic diameter of the channel.

$$
h=\frac{N u_{D} k}{D_{h}} .
$$

As mentioned earlier, the effective UA of the heat exchanger was of interest. The UA for the full heat exchanger was determined by equation 5 , where $\mathrm{n}$ is the total number of channels, $\eta_{\mathrm{o}}$ is the surface efficiency, and $\mathrm{A}_{\mathrm{s}}$ is the total cooled surface area of the channel. The surface efficiency was estimated by treating the fin as a standard straight rectangular fin [10].

$$
U A=n \eta_{o} h A_{s} .
$$

In addition to the UA value, it was also of interest to evaluate the pressure drop through the channel. The pressure drop due to the channel is determined based on equation 6, where $l$ is the channel length, $r$ is the fluid density, and $u_{m}$ is the mean fluid velocity through the channel $[10,11]$. Equation 6 considers only the channel pressure drop, but entry and exit loss coefficients could also be included. These were excluded for this analysis in order to compare the results to the pressure drop from the CFD results.

$$
\Delta P=f \frac{l}{D_{h}} \frac{\rho u_{m}^{2}}{2} .
$$

\section{Heat Exchanger Characterization - Jet}

The approach to characterize the finned heat exchanger used analytical solutions and CFD results. The third approach described in this paper provides an example of using correlations based on experimental work. For this example, experimental work performed at the NREL on jet cooling was used [12]. NREL researchers characterized the performance of steady and self-oscillating single-phase jets in submerged and free surface conditions. This analysis focused on the data associated with the steady jet in the submerged condition. The target distance between the jet outlet and the impingement surface was $1.1 \mathrm{~mm}$. The jet velocity was $2 \mathrm{~m} / \mathrm{s}, 7 \mathrm{~m} / \mathrm{s}$, and 12 $\mathrm{m} / \mathrm{s}$. The jet diameter was fixed at $1.24 \mathrm{~mm}$, the coolant fluid was water at an inlet temperature of $25^{\circ} \mathrm{C}$, and the heated target area was $1.27 \mathrm{~cm}^{2}$.

Since the data are based on water at $25^{\circ} \mathrm{C}$ it was necessary to estimate the jet performance for a $50 \%$ by mass mixture of water ethylene glycol at the desired temperatures of $70^{\circ} \mathrm{C}$ and $105^{\circ} \mathrm{C}$. For this reason, the reported performance data were converted into a generalized dimensionless form based on Reynolds number $\left(\mathrm{Re}_{\mathrm{D}}\right)$ and Colburn factor $\left(\mathrm{j}_{\mathrm{H}}\right)$ using equations 7 though 9, where St is the Stanton number, Pr is the Prandtl number, $c_{p}$ is the fluid specific heat, and $\mu$ is the fluid dynamic viscosity. The results are plotted in Fig. 8 along with a curve fit of the data correlating the Colburn factor to Reynolds number. Using the correlation, it is possible to back out estimates for the heat transfer coefficient with jets using water ethylene glycol assuming a desired jet velocity. In this analysis, the mean jet velocity was kept consistent with the experimental results. An exhaustive approach was not used to refine the jet correlation. The intent was to show the process and obtain approximate values using jets with water ethylene glycol. 


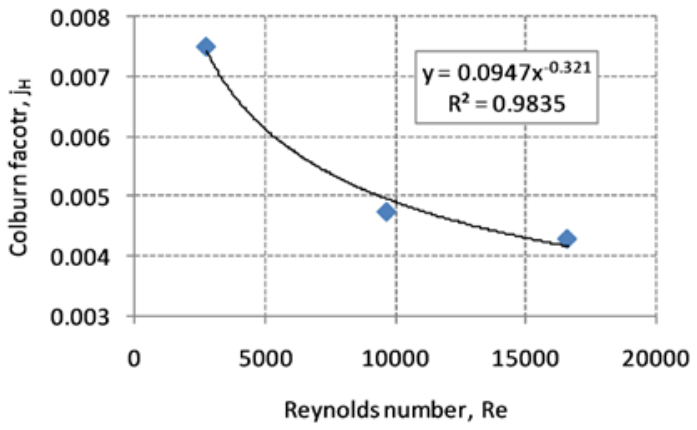

Figure 8. Experimental results for submerged single-phase jet (target distance $1.1 \mathrm{~mm}$, jet diametert $1.24 \mathrm{~mm}$, water inlet temperature $25^{\circ} \mathrm{C}$ ).

$$
\begin{gathered}
j_{h}=S t \operatorname{Pr}^{2 / 3} . \\
S t=\frac{h}{\rho u_{m} c_{p}} . \\
R e_{D}=\frac{\rho u_{m} D_{h}}{\mu} .
\end{gathered}
$$

\section{Heat Exchanger Effectiveness-NTU Analysis}

When evaluating the performance of heat exchangers, it is important not to neglect the impact of the coolant fluid properties and flow rate. Often, simplifications are used that approximate the thermal resistance of the heat exchanger as simply 1/UA, but this can lead to inaccurate estimates of heat exchanger performance [13]. For this reason, the performance of the previously discussed cooling channels will be compared in terms of the effectiveness-NTU (number of transfer units) thermal resistance shown in equation 10 , where $\varepsilon$ is the heat exchanger effectiveness and $\dot{m}$ is the fluid mass flow rate. The heat exchanger effectiveness is calculated from the NTU, as shown in equations 11 and 12 (see [10] and [13] for details).

$$
\begin{aligned}
& R_{N T U}=\frac{1}{\varepsilon \dot{m} c_{p}} . \\
& \varepsilon=1-e^{-N T U} . \\
& N T U=\frac{U A}{\dot{m} c_{p}} .
\end{aligned}
$$

Fig. 9 compares actual thermal resistance $\mathrm{R}_{\mathrm{NTU}}$ against the simplified ideal thermal resistance (1/UA) across a range of UA values. As UA increases, the actual thermal resistance departs from the ideal case, and as expected, it is dependent on the flow rate for a specified fluid. For example, the results for $12 \mathrm{~L} / \mathrm{min}$ depart from the ideal case for UA greater than 10 $\mathrm{W} / \mathrm{K}$.

\section{RESULTS}

\section{A. Package Thermal Characterization}

As shown in Fig. 1, an initial requirement to evaluate the system performance of a power semiconductor package is an understanding of the package specific thermal performance. The package specific thermal performance curves are shown in
Fig. 10 for the selected package. The curves show the package thermal performance against a range of potential heat exchanger performance characteristics. Specifically, the curves show the maximum allowable heat flux through the IGBT vs. heat exchanger thermal resistance based on the specified temperature limits. These curves were generated by iterating on the volumetric heat generation of the IGBT and diode until the specified peak IGBT junction temperature limit was reached. A 3:1 ratio was used for the IGBT to diode losses.

Three conditions were developed based on different temperature specifications for the inlet coolant and the maximum allowable junction temperature. The baseline curve shows the thermal performance, assuming a $70^{\circ} \mathrm{C}$ inlet coolant temperature and an IGBT junction temperature limit of $150^{\circ} \mathrm{C}$. The second curve represents a $105^{\circ} \mathrm{C}$ coolant temperature and $150^{\circ} \mathrm{C}$ junction temperature, while the third represents a $70^{\circ} \mathrm{C}$ coolant temperature and $175^{\circ} \mathrm{C}$ junction temperature limit. Two key points to notice are how the curves begin to flatten at low heat exchanger thermal resistance values and, as expected, the $105^{\circ} \mathrm{C}$ coolant temperature causes a drop in achievable heat flux.

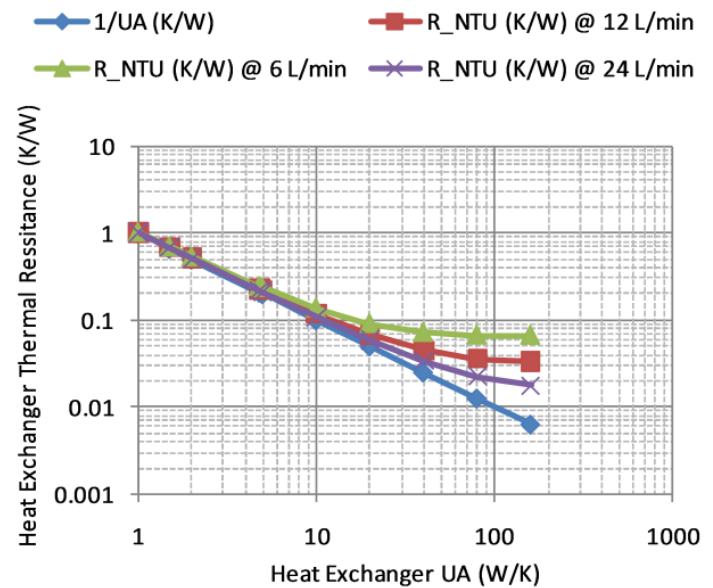

Figure 9. Comparison of actual and ideal (1/UA) thermal resistance as a function of UA for $50 \%$ by mass mixture of water ethylene glycol at $70^{\circ} \mathrm{C}$ at three flow rates.

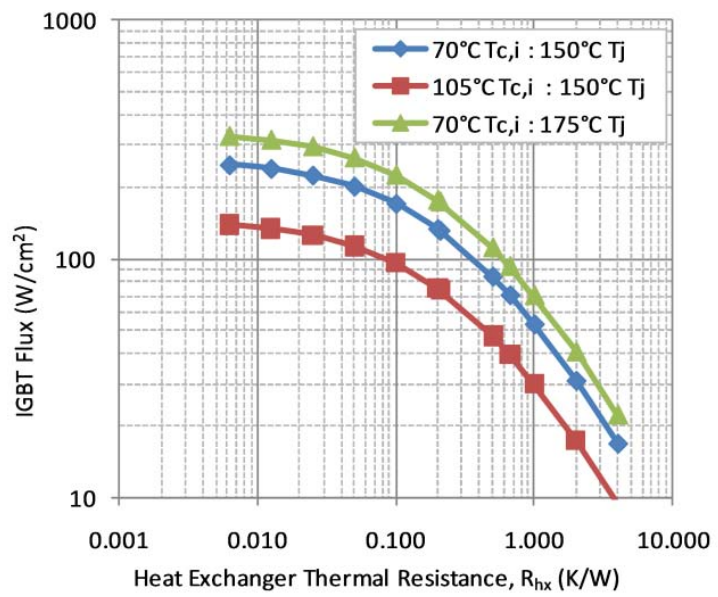

Figure 10. Package specific thermal performance curves showing IGBT heat flux vs. heat exchanger thermal resistance at three operating conditions. 
In this analysis, the different temperature specifications were modeled in the 3D FEA model. It is also possible to estimate the impact of different temperature specifications without running all combinations, which is important in analyzing the impact of alternative coolant temperatures and the effects of increasing component temperature limits. To determine the impact of alternative temperature specifications on a fixed package, the baseline model results must first be generated. The result for the case of a $70^{\circ} \mathrm{C}$ inlet coolant temperature and an IGBT junction temperature limit of $150^{\circ} \mathrm{C}$ (shown in Fig. 10) was selected as the baseline. For each operating point, it is possible to estimate the total thermal resistance from junction to fluid $\left(\mathrm{R}_{\mathrm{tot}}\right)$ according to equation 13 , where $T_{j}$ is the allowable junction temperature limit, $T_{c, i}$ is the coolant inlet temperature, and $\mathrm{q}_{\text {tot }}$ is the total heat applied to the package (IGBT + diode). It is then possible to estimate the IGBT heat flux (q" IGBT) assuming different temperature specifications following equations 14 through 16. A fixed loss ratio of 3:1 between the IGBT and diode is assumed, and $\mathrm{A}_{\mathrm{Si}, \mathrm{IGBT}}$ is the silicon area of the IGBT device.

$$
\begin{aligned}
R_{t o t} & =\frac{T_{j}-T_{c, i}}{q_{t o t}} . \\
q_{t o t} & =\frac{\Delta T}{R_{t o t}} . \\
q_{I G B T} & =\frac{3}{4} q_{t o t} . \\
q_{I G B T}^{\prime \prime} & =\frac{q_{I G B T}}{A_{S i, I G B T}} .
\end{aligned}
$$

Fig. 11 shows a comparison of the results. The estimated values based on equations 13 through 16 match the actual simulated results from the 3D FEA model. The agreement between results gives confidence in the ability to investigate multiple temperature specification options without the need to run numerous 3D FEA simulations.

It is also important to evaluate the impact of potential changes to the package configuration. For example, it is also possible to look at the sensitivity of performance to other factors, such as material selection. As an example, the TIM thermal properties were adjusted as shown in Table II. Fig. 12 shows the results. For high heat exchanger thermal resistance values $\left(\mathrm{R}_{\mathrm{hx}}\right)$, the heat exchanger is the bottleneck, and package thermal improvements become less effective. The curves show that different package configurations with different package thermal resistance characteristics approach the same value of heat flux as $R_{h x}$ increases. It is necessary to decrease $R_{h x}$ to get the benefit of improved thermal performance packages with reduced thermal resistance. As $R_{h x}$ decreases, the package curves level off at different rates based on the package thermal performance.

\section{B. Heat Exchanger Characterization}

With the information generated for the package thermal performance, the next step required understanding the performance of the potential heat exchanger technologies. As highlighted previously, this work looked at the performance of an aluminum fin heat exchanger and a jet impingement heat exchanger. Table $\mathrm{V}$ highlights the performance of the finned heat exchanger for the operating conditions in Tables III and IV. Table V compares the results of the CFD analysis with the analytical solution. The results are relatively close given the assumptions applied to the analytical solution. Specifically, the difference in the heat transfer coefficient is expected because the analytical solution assumed a fully developed thermal region and uniform temperature. However, the pressure drops are close because both solutions are based on fully developed flow through the channel.

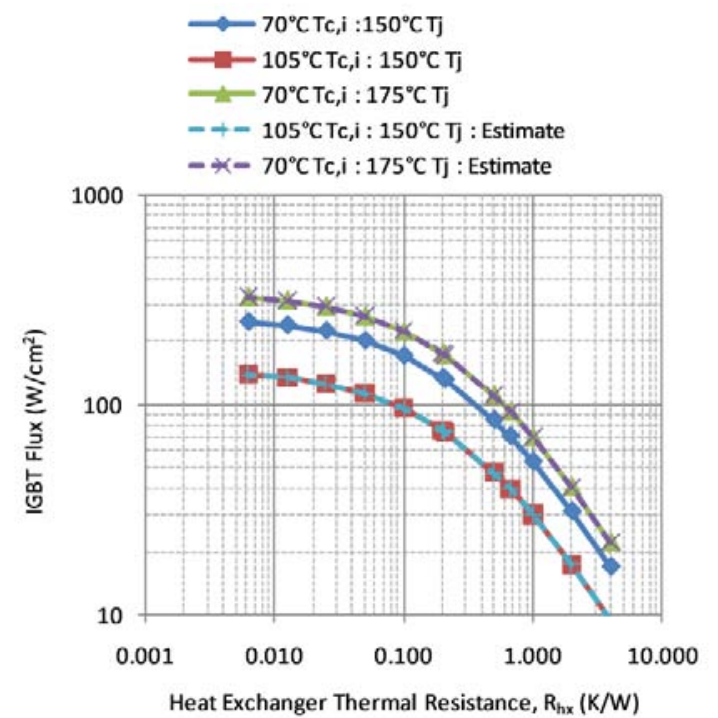

Figure 11. Comparison of simulated and estimated performance curves for alternative temperature specifications.

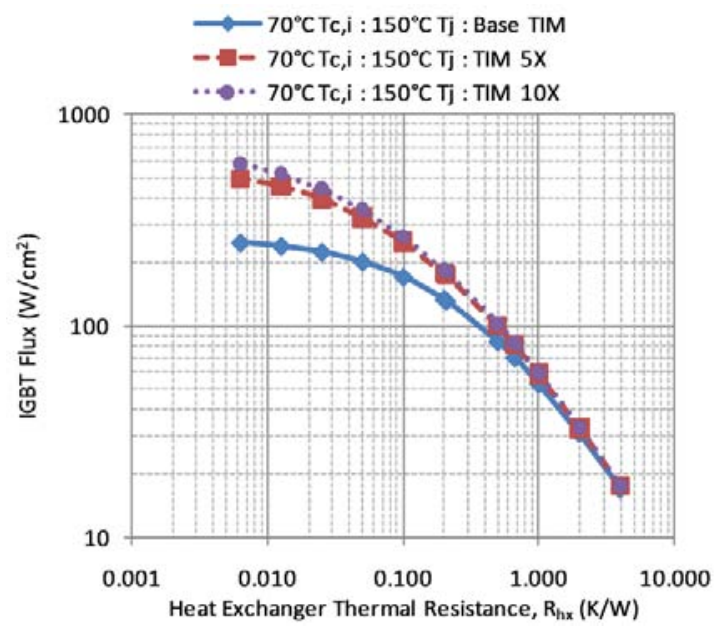

Figure 12. Comparison package performance with improved thermal interface material.

TABLE V

FIN RESULTS COMPARISON

\begin{tabular}{|c|c|c|}
\hline Parameter & CFX & Analytical Value \\
\hline $\mathrm{h}\left(\mathrm{W} / \mathrm{m}^{2}-\mathrm{K}\right)$ & 1877 & 1241 \\
\hline $\mathrm{nhA}(\mathrm{W} / \mathrm{K})$ & 10.89 & 6.2 \\
\hline $\mathrm{UA}_{\mathrm{b}}(\mathrm{W} / \mathrm{K})$ & 10.38 & 271 \\
\hline$\triangle \mathrm{P}(\mathrm{Pa})$ & 267 & 0.16 \\
\hline$\frac{1}{\varepsilon \dot{m} c_{p}}(\mathrm{~W} / \mathrm{K})$ & 0.11 & \\
\hline
\end{tabular}


The estimated convection heat transfer coefficients for the jet impingement cooling are provided in Fig. 13 and were generated following the previously developed correlation (Fig. 8). Fig. 13 shows the estimated performance of a submerged steady jet at $70^{\circ} \mathrm{C}$ and $105^{\circ} \mathrm{C}$ using a $50 \%$ by mass mixture of water ethylene glycol. The experimental convection heat transfer coefficient values were based on an average temperature over a heated area, so the results would not be the same if the temperatures were averaged over a different area. The specified convection coefficient values are tied to a specific area.

For this analysis, it was assumed that the jet would not provide a high convection coefficient over the entire heat exchanger surface used in Fig. 2 and Fig. 4 (30 mm by $50 \mathrm{~mm}$ ). For this reason, the selected convection coefficient for one jet was assumed to be over a $1.27 \mathrm{~cm}^{2}$ area. Because of this smaller area, two jets were applied to each side of the package, which doubles the total system flow rate if the flow rate through a single jet was kept constant at $0.5 \mathrm{~L} / \mathrm{min}$. This is shown in Table VI for the assumed system flow rate. Using $1.27 \mathrm{~cm}^{2}$ represents the low-end thermal performance, because additional area on the heat exchanger would experience some cooling. For this reason, a doubling of the effective cooling area was also considered with the intent to show the potential range of performance. A more detailed investigation would need to be performed to determine the actual area averaged convection coefficient using jet cooling for this specific package since, for jet cooling, the local convection coefficient decreases away from the jet impingement area.

Table VI shows the performance of the jet cooling at the two effective area assumptions. One can see that the idealized thermal resistance (1/UA) is close to the effectiveness-NTU thermal resistance even at the higher UA values because of the higher flow rate. This is confirmed by Fig. 9. The results are shown at an inlet coolant temperature of $70^{\circ} \mathrm{C}$ and $105^{\circ} \mathrm{C}$.

\section{System Performance}

With the generated package performance curves and the completed heat exchanger analysis, it was possible to combine the two results to the look at the total system performance as shown in the general process diagram of Fig. 1. This was done by overlaying the heat exchanger performance in terms of its effectiveness-NTU thermal resistance on top of the generated package thermal performance curves, as shown in Fig. 14. This allowed a comparison of the combined system and an understanding of how improvements in the heat exchanger performance affect the system performance. Fig. 14 highlights four package performance curves. The first is the baseline system with the base TIM, inlet coolant temperature of $70^{\circ} \mathrm{C}$, and a maximum junction temperature of $150^{\circ} \mathrm{C}$. The second curve is the same package with an inlet coolant temperature of $105^{\circ} \mathrm{C}$. The third curve is the same as the baseline system, except the TIM thermal resistance is reduced by a factor of 10 . Finally, the fourth performance curve included the $10 \mathrm{X}$ improved thermal interface material and an inlet coolant temperature of $105^{\circ} \mathrm{C}$. The heat exchanger performance is shown in Fig. 14 by the vertical lines. Three representative heat exchangers are shown. The first is the double jet at the lower limit of the effective heat exchanger area. As can be seen, its

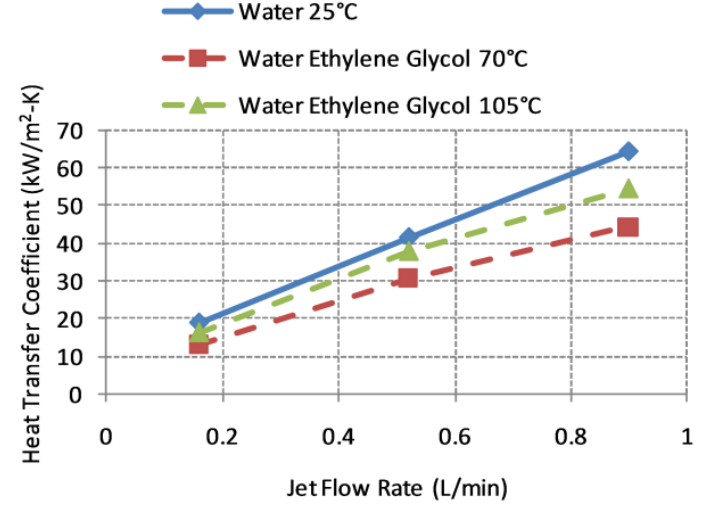

Figure 13. Comparison of convection heat transfer coefficient vs. flow rate for water at $25^{\circ} \mathrm{C}$ and jets using a $50 \%$ by mass mixture of water ethylene glycol at $70^{\circ} \mathrm{C}$ and $105^{\circ} \mathrm{C}$.
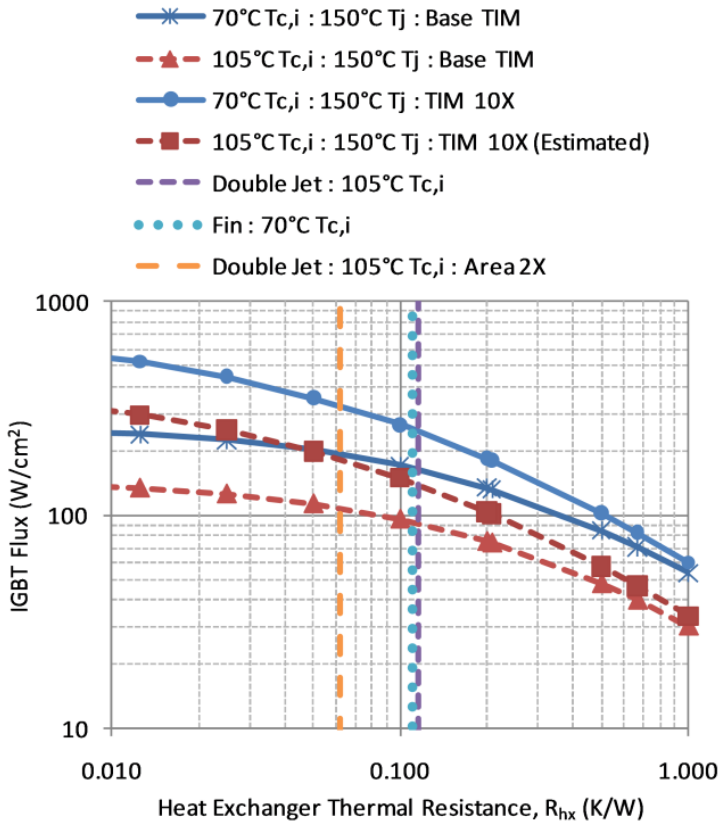

Figure 14. System performance showing package thermal performance curves with estimated heat exchanger performance.

TABLE VI JET RESULTS ESTIMATE

\begin{tabular}{|c|c|c|c|c|}
\hline & \multicolumn{2}{|c|}{ Two Jets per Side } & \multicolumn{2}{c|}{$\begin{array}{c}\text { Two Jets per Side } \\
\text { 2X Area } \\
\text { Enhancement }\end{array}$} \\
\hline System flow $[\mathrm{L} / \mathrm{min}]$ & 24 & 24 & 24 & 24 \\
\hline $\mathrm{T}_{\mathrm{c}, \mathrm{i}}\left[{ }^{\circ} \mathrm{C}\right]$ & 70 & 105 & 70 & 105 \\
\hline Flow per Jet $[\mathrm{L} / \mathrm{min}]$ & 0.5 & 0.5 & 0.5 & 0.5 \\
\hline $\mathrm{h}\left[\mathrm{W} / \mathrm{m}^{2}-\mathrm{K}\right]$ & 30000 & 37000 & 30000 & 37000 \\
\hline Cooled Area $\left[\mathrm{m}^{2}\right]$ & $2.53 \mathrm{E}-04$ & $2.53 \mathrm{E}-04$ & $5.07 \mathrm{E}-04$ & $5.07 \mathrm{E}-04$ \\
\hline $\mathrm{UA}[\mathrm{W} / \mathrm{K}]$ & 7.60 & 9.37 & 15.20 & 18.75 \\
\hline $1 / \mathrm{UA}[\mathrm{K} / \mathrm{W}]$ & 0.132 & 0.107 & 0.066 & 0.053 \\
\hline 1 & 0.140 & 0.115 & 0.074 & 0.062 \\
\hline$\varepsilon \dot{m} c_{p}[\mathrm{~K} / \mathrm{W}]$ & & & & \\
\hline
\end{tabular}

thermal performance is close to the baseline finned heat exchanger at a $70^{\circ} \mathrm{C}$ inlet coolant temperature. Although not shown, the thermal resistance of the finned heat exchanger at 
$105^{\circ} \mathrm{C}$ is similar. Finally, the third heat exchanger shows the potential of a two times improvement in the heat exchanger area for the double jet system.

In the case of the baseline system, one can see that the benefit of increasing the heat exchanger performance beyond the fin design is of limited value because of the limitation related to the package thermal performance. This is because of the leveling off of the curve at lower $\mathrm{R}_{\mathrm{hx}}$ values. Fig. 14 also shows the impact of increasing the coolant temperature. While the system at $70^{\circ} \mathrm{C}$ coolant is capable of operating at about 165 $\mathrm{W} / \mathrm{cm}^{2}$, this is decreased to $93 \mathrm{~W} / \mathrm{cm}^{2}$ when forced to operate with a coolant temperature of $105^{\circ} \mathrm{C}$ (a drop of $44 \%$ ). This assumes similar performance for the finned heat exchanger at $70^{\circ} \mathrm{C}$ and $105^{\circ} \mathrm{C}$. As shown in Fig. 14 , the package with the improved TIM is able to take advantage of a higher performance heat exchanger.

Finally, since the selected package is part of an existing HEV application, the estimated system performance from this analysis was compared against publicly available information. For this comparison, the total thermal resistance $\left(R_{\text {tot }}\right)$ from junction to fluid was calculated using equation 13 with the fluid temperature at $70^{\circ} \mathrm{C}$ and junction temperature at $150^{\circ} \mathrm{C}$. The total thermal resistance at the estimated finned heat exchanger thermal resistance $(0.11 \mathrm{~K} / \mathrm{W})$ is $0.219 \mathrm{~K} / \mathrm{W}$. For comparison, the published maximum thermal resistance of the package is $0.203 \mathrm{~K} / \mathrm{W}[2,3]$. This is within $8 \%$ of the published value.

\section{CONCLUSIONS}

This paper describes a method of integrating techniques for characterizing power semiconductor thermal performance and heat exchanger technologies. The methodology enables an analysis of the system performance and the trade-offs of a combined cooling system. A production power semiconductor package capable of double-sided cooling was selected to demonstrate the process and analysis techniques. Package specific thermal performance curves were generated comparing the achievable IGBT heat flux to a specified heat exchanger thermal resistance operating at specified temperatures. Methods for using fluid and thermal data from analytical solutions, CFD results, and experimental correlations were illustrated, with their application to standard heat exchanger analysis techniques. The importance of not relying on the ideal thermal resistance (1/UA) based only on convection was also demonstrated. Even for fully developed laminar flow, the selection of the mass flow rate is important in terms of heat exchanger effectiveness, which affects the error of the simplified 1/UA thermal resistance model.

It is important to note the importance of matching the heat exchanger thermal performance $\left(R_{h s}\right)$ with the package thermal performance. The optimal heat transfer mechanism is highly dependent on the package configuration, which leads to the need to evaluate the package and heat exchanger as an integrated system. The combined analysis ensures that one area of the thermal control system is not overdesigned, adding unnecessary cost, weight, and volume to the system. The work described in this paper illustrates the need for an integrated system analysis on new innovative power semiconductor package configurations, and proposes techniques for understanding the trade-offs associated with an integrated system.

\section{ACKNOWLEDGMENT}

We thank Tim Burress of Oak Ridge National Laboratory for providing information about the selected package construction. We also acknowledge the support of Sreekant Narumanchi and Lawrence Chaney of NREL.

\section{REFERENCES}

[1] Electrical and Electronics Technical Team Roadmap, FreedomCAR and Fuels Partnership, November 2006, www.eere.energy.gov/vehiclesandfuels/pdfs/program/eett_roadmap.pdf.

[2] Y. Sakai, H. Ishiyama, and T. Kikuchi, "Power control unit for high power hybrid system," SAE 2007 World Congress, Detroit, MI, April 16-19, 2007, SAE Paper 2007-01-0271.

[3] H. Yasui, H. Ishiyama, M. Inagaki, K. Mamitsu, and T. Kikuchi, "Power control unit for high power hybrid system," Proceedings of the EVS 23 conference, Anaheim, CA, Dec. 2-5, 2007.

[4] J. Hsu, R. Staunton, and M. Starke, "Barriers to the Application of HighTemperature Coolants in Hybrid Electric Vehicles," Oak Ridge National Laboratory Technical Report ORNL/TM-2006/514, 2006.

[5] K. Kelly et al.,"An overview of thermal control technologies for cooling electric vehicle power electronics," Proceedings of the EVS 23 conference, Anaheim, CA, Dec. 2-5, 2007.

[6] M. O'Keefe and K. Bennion, "A comparison of hybrid electric vehicle power electronics cooling options," Vehicle Power and Propulsion Conference, Sept. 9-12, 2007.

[7] T. Burress et al.,"Evaluation of the 2008 Lexus LS 600H Hybrid Synergy Drive System," Oak Ridge National Laboratory Technical Report ORNL/TM-2008/185, 2009.

[8] S. Narumanchi, M. Mihalic, K. Kelly, and G. Eesley, "Thermal interface materials for power electronics applications," ITHERM 2008, May 28$31,2008$.

[9] K. Alshamani, "Equations for physical properties of automotive coolants," SAE 2003 World Congress, March 3-6, 2003, SAE Paper 2003-01-0532.

[10] F. Incropera and D. DeWitt, Fundamentals of Heat and Mass Transfer, 4th ed. John Wiley and Sons, New York, 1996.

[11] B. Munson, D. Young, and T. Okiishi, Fundamentals of Fluid Mechanics, 3rd ed., John Wiley and Sons, New York, 1998.

[12] S. Narumanchi, K. Kelly, M. Mihalic, S. Gopalan, R. Hester, and A. Vlahinos, "Single-phase self-oscillating jets for enhanced heat transfer," Semi-Therm 2008, March 16-20, 2008.

[13] R. Moffat, "Modeling air-cooled heat sinks as heat exchangers," SEMITHERM 2007, March 18-22, 2007. 


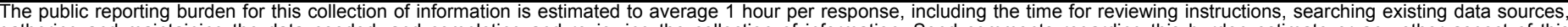

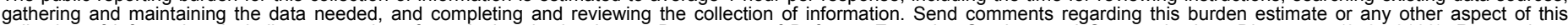

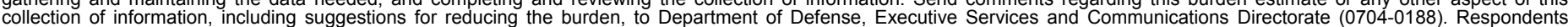

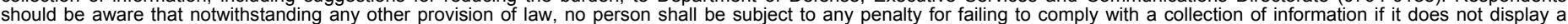

should be aware that notwithstanding

PLEASE DO NOT RETURN YOUR FORM TO THE ABOVE ORGANIZATION.
1. REPORT DATE (DD-MM-YYYY) August 2009
4. TITLE AND SUBTITLE
Rapid Modeling of Power Electronics Thermal Management
Technologies: Preprint

3. DATES COVERED (From - To)

5a. CONTRACT NUMBER

DE-AC36-08-GO28308

5b. GRANT NUMBER

5c. PROGRAM ELEMENT NUMBER

5d. PROJECT NUMBER

NREL/CP-540-46172

5e. TASK NUMBER

FC087000

5f. WORK UNIT NUMBER
7. PERFORMING ORGANIZATION NAME(S) AND ADDRESS(ES)

National Renewable Energy Laboratory

1617 Cole Blvd.

Golden, CO 80401-3393

\section{PERFORMING ORGANIZATION REPORT NUMBER \\ NREL/CP-540-46172}

9. SPONSORING/MONITORING AGENCY NAME(S) AND ADDRESS(ES)

\section{SPONSOR/MONITOR'S ACRONYM(S)} NREL

11. SPONSORING/MONITORING AGENCY REPORT NUMBER

12. DISTRIBUTION AVAILABILITY STATEMENT

National Technical Information Service

U.S. Department of Commerce

5285 Port Royal Road

Springfield, VA 22161

13. SUPPLEMENTARY NOTES

14. ABSTRACT (Maximum 200 Words)

A methodology was developed to rapidly evaluate trade-offs associated with alternative packaging configurations and thermal management technologies for power electronics packaging. The methodology includes the integration of available experimental correlations, computational fluid dynamics results, parametric 3D finite element analysis (FEA) thermal models, and established heat exchanger analysis techniques. The parametric 3D FEA model enables sensitivity studies related to the power module package configuration and cooling technologies. This paper focuses on the study of alternative cooling technologies as they are applied to a fixed power module package. The methodology is applied to a double-sided power module package for several alternative cooling technologies.

15. SUBJECT TERMS

power electronics; thermal management; thermal control; thermal resistance; hybrid electric vehicles; electric vehicle; fuel cell vehicles

\begin{tabular}{|c|c|c|c|c|}
\hline \multicolumn{3}{|c|}{ 16. SECURITY CLASSIFICATION OF: } & 17. LIMITATION & 18. NUMBER \\
\hline $\begin{array}{l}\text { a. REPORT } \\
\text { Unclassified }\end{array}$ & $\begin{array}{l}\text { b. ABSTRACT } \\
\text { Unclassified }\end{array}$ & $\begin{array}{l}\text { c. THIS PAGE } \\
\text { Unclassified }\end{array}$ & $\begin{array}{c}\text { OF ABSTRACT } \\
\text { UL }\end{array}$ & \\
\hline
\end{tabular}

19a. NAME OF RESPONSIBLE PERSON

19b. TELEPHONE NUMBER (Include area code) 